\title{
Political Economy Analysis of the Production and Marketing of Shea Nut Products by Women in the Northern Region of Ghana
}

\author{
Martha Adimabuno Awo ${ }^{1} \&$ Kwabena Asomanin Anaman ${ }^{1}$ \\ ${ }^{1}$ Institute of Statistical, Social and Economic Research, University of Ghana, Legon, Accra, Ghana \\ Correspondence: Kwabena Asomanin Anaman, Professor, Institute of Statistical, Social and Economic Research, \\ University of Ghana, Legon, Accra, Ghana. E-mail: kwabenaasomanin@hotmail.com; kanaman@ug.edu.gh \\ Received: September 11, 2015 \\ doi:10.5430/rwe.v6n4p1 \\ Accepted: October 5, 2015 \\ Online Published: November 27, 2015 \\ URL: http://dx.doi.org/10.5430/rwe.v6n4p1
}

\begin{abstract}
Shea nut, a crop which is currently picked mostly by women in the wild, offers an opportunity for empowering women to increase their incomes and reduce overall poverty in the three northern regions of Ghana (Upper East, Upper West and Northern). These three regions have very high absolute poverty levels, both in the Ghanaian and African contexts, with women bearing the greater burden of the poverty. This paper was based on a survey of 226 women farmers in the Northern Region of Ghana which is the most important producing shea nut producing region of Ghana. Farmers' satisfaction for prices received for shea products was linked to their membership of farmer-based organizations, having savings accounts and having enforceable contracts with buyers. There were extensive market failures in the production and processing of shea nut products. The reduction of these market failures has largely been undertaken through efforts from farmer-based organizations. Some government intervention is required to help to improve market outcomes and livelihoods of the women.
\end{abstract}

Keywords: agriculture, Northern Ghana, peasant farming, shea nut, women farmers

\section{Introduction}

The shea tree (Vitellara paradoxa) is found in a long narrow swath approximately 600 kilometres $(\mathrm{km})$ wide and $5,000 \mathrm{~km}$ long across northern Sub-Saharan Africa, encompassing 20 countries from Senegal in the west to Sudan and Uganda (and a small corner of Ethiopia) in the east (Elias and Carney, 2007, p. 38; Figure 1). The shea tree is indigenous to the semi-arid zones of sub-Saharan Africa above the equator (Bonkoungou, 1987). The tree is found extensively in the Guinea Savannah and less abundantly in the Sudan Savannah (Food and Agriculture Organisation, 1988). The tree thrives on about 1,167 acres of lands located in the northern and some part of the middle belt of the country, occupying almost half of Ghana and covers the entire area of Northern Ghana. The trees are found in smaller quantities in the Southern Ghana.

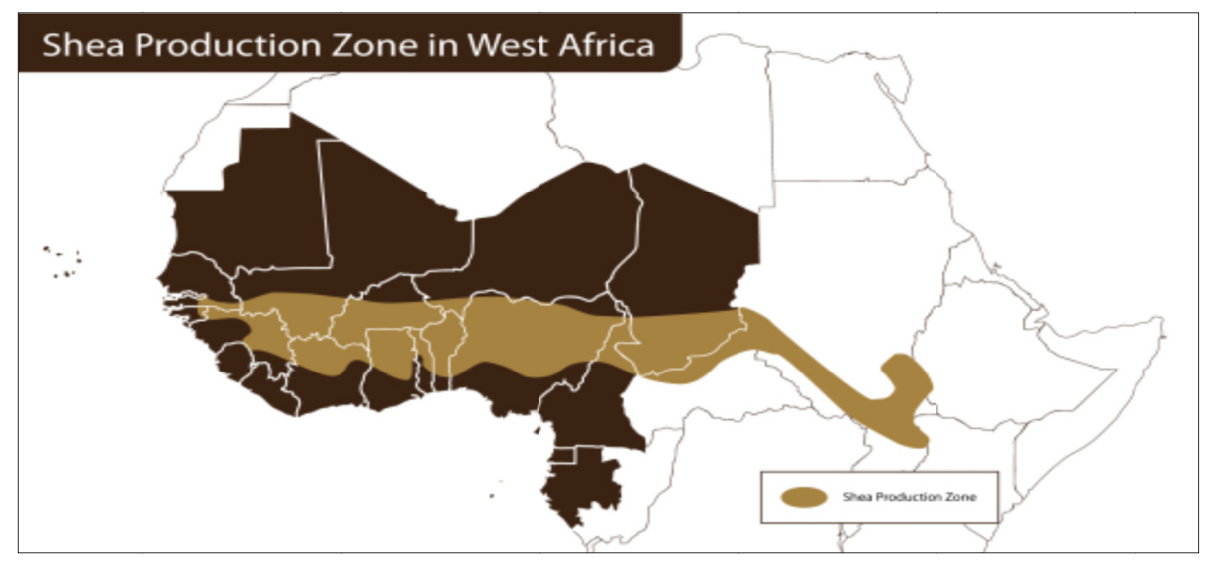

Source: Elias and Carney, 2007, p. 38.

Figure 1. The African shea belt 
The shea trees are naturally occurring savannah forest crop found mostly in the northern parts of Ghana. The shea plant is part of the culture of the people of Northern Ghana and it is used in many facets of life. The leaves, back and roots are important for medicinal purpose. The stem has been used to support building structures and together with its branches, they serve as efficient firewood for households, though it is seldom used. The yet to be fully explored copious sap is reported to be an important source of raw material for gum and the rubber industry. The kernel and butter have so far proven the component with the greatest economic value for now.

The shea sector contributes to national development from four main angles; foreign exchange, food security, employment generation and poverty alleviation. The shea sector which is classified as a non-traditional export commodity by the Ghana Export Promotion Authority (GPA) has in recent years been contributing significantly to the national foreign income generation (Figures 2 and 3). In 2011, shea butter generated about 27.61 million US dollar foreign exchange with an increase of $16.84 \%$ over the previous year (Figure 2). In that same year, shea nut generated about 25.09 million US dollars foreign exchange value. This was an increase of $80.76 \%$ over the previous year (see Figure 3).

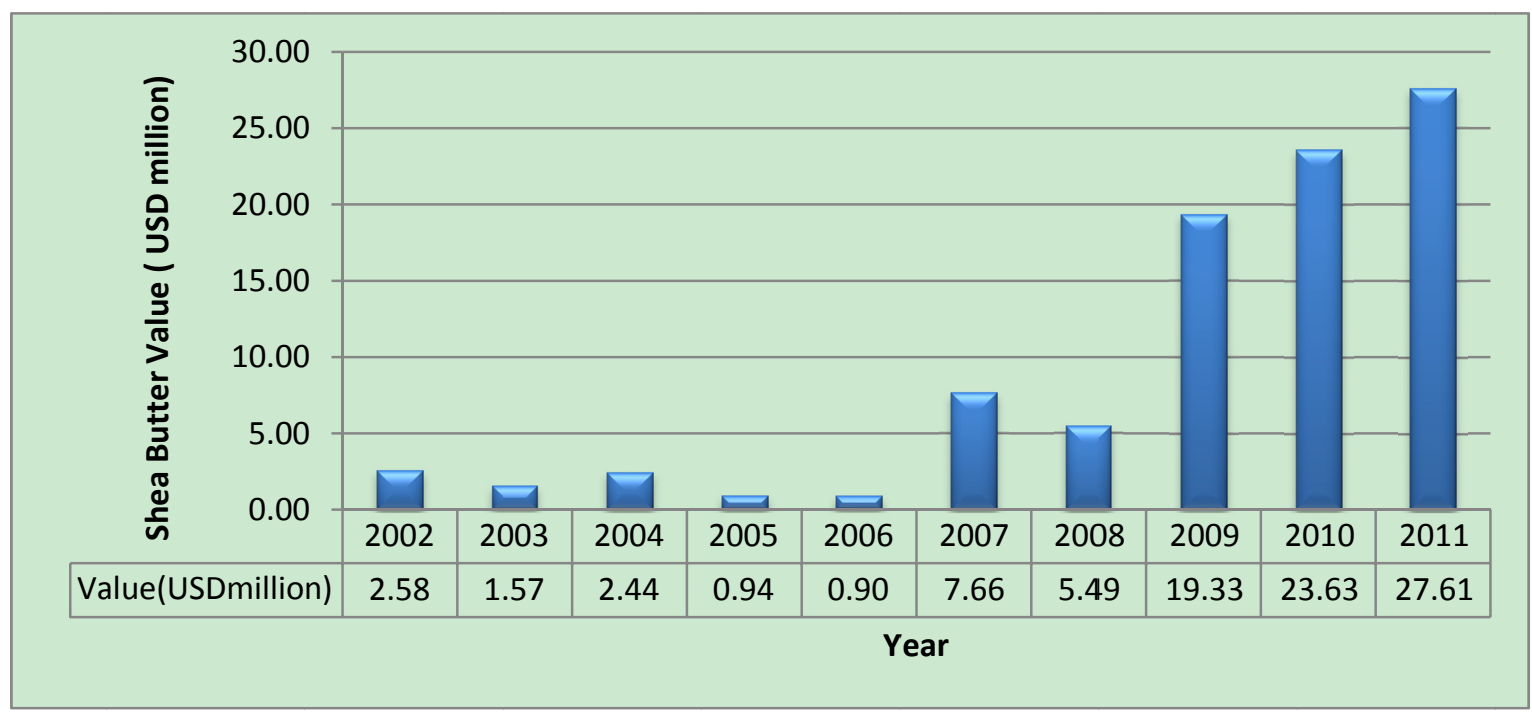

Source: Compilations from Ghana Cocoa Board and Ghana Export Promotion Council (2013).

Figure 2. Trends in export value of shea butter in Million US Dollars (2002-2011)

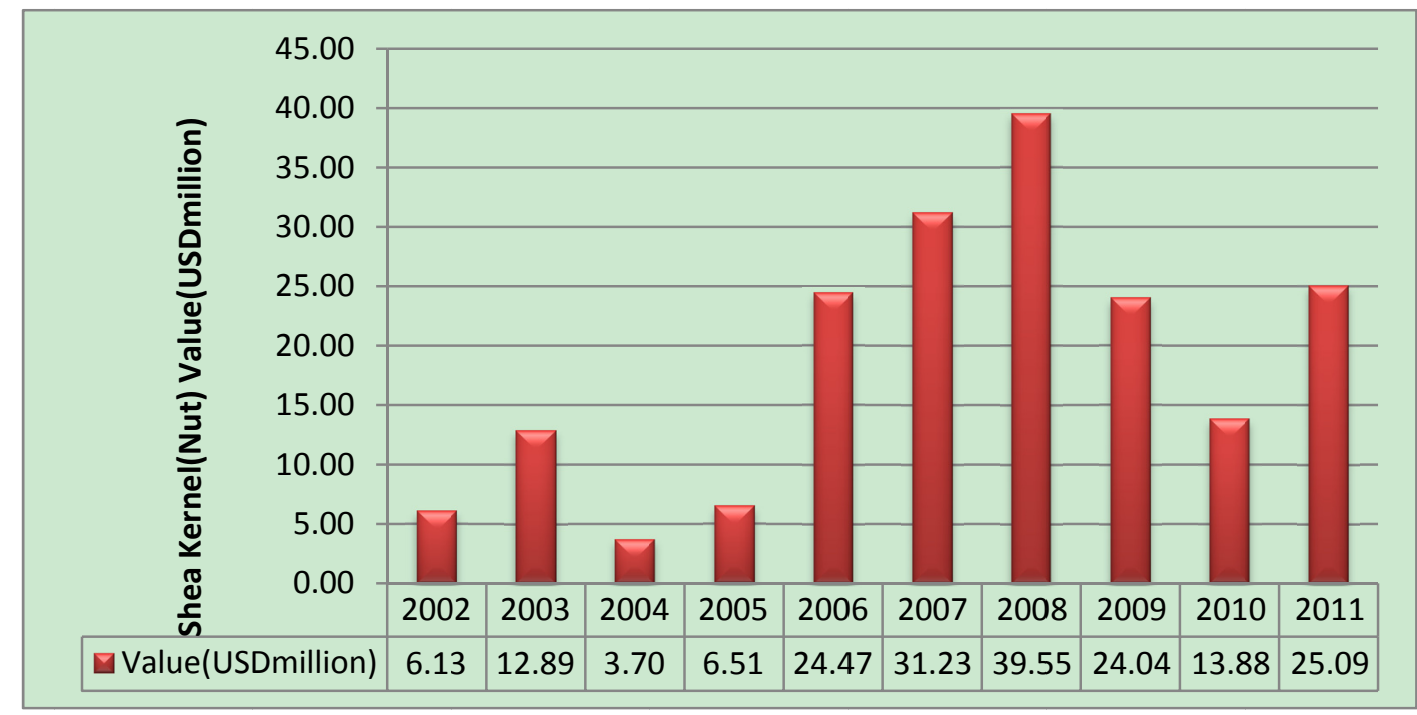

Source: Compilations from Ghana Cocoa Board and Ghana Export Promotion Council (2013).

Figure 3. Trends in export value of shea nut in Million US Dollars (2002-2011) 
In Northern Ghana, the production of shea nut and shea butter has traditionally been the preserve of women. The passage of shea butter production to young girls forms part of the transition to womanhood as well as impartation of livelihood skills. The shea butter has traditionally been used as a vegetable oil for cooking, pomade for the hair and skin, in soap preparation, in ointment and other medicinal preparations, water proofing for walls, lamp fuels and other undocumented purposes (Addaquay, 2004; Lovett et al., 2005). Even before the global popularity of shea butter, women engaged in its production for household consumption and establishment of social bond through its use as gift, marriage and funeral rites.

As established by various rounds of the Ghana Living Standards Survey (GLSS), the poverty levels of people in the three northern regions of Ghana ((Upper East, Upper West and Northern) are very high; they are the highest in Ghana with women bearing the greater burden of the poverty (Ghana Statistical Service, 2014). With average poverty levels in these three regions well over $70 \%$, as established in the sixth round of GLSS which was concluded in 2013, these regions also have some of the highest poverty levels in Africa.

Shea production has been identified as a major source of dealing with food security and poverty in these three northern regions of Ghana (Hatskevich et al., 2011; Chalfin, 2004). Stathacos (2004) indicated that, over 600,000 women in Northern Ghana depend on shea for their livelihood. Activities in the shea sector are at its peak at early planting season when household money and food are scarce. Women in Northern Ghana by custom are expected to contribute to household food needs by essentially providing the daily protein and vitamin needs. They go to market places to buy meat/fish, vegetables, oils and other condiments to prepare meals. Aside the shea sector providing additional cash income for households, the harvested fresh shea fruits also provide substantial amount of daily food needs from its fleshy pulps which are eaten as fruits (Hall et. al, 1996).

Women who dominate the sector are the most vulnerable especially in the recent era of interventions by non-governmental organizations (NGO) and the government of Ghana aimed at increasing the internationalisation of the sector. In recent years, there has been rapid demand for shea products as a result of shea market growth. However, there are challenges to the realisation of the full potential of the sector to their livelihood. The cause of this challenge, Addaquay (2011) identified to be (1) concerns about sustainability and consistency of product quality, (2) limited organization of rural producers into efficient business enterprises, (3) weak linkages between rural producers and buyers, (4) limited participation of and support for women in the broader business environment and (5) fragmentation and weaknesses in the broader shea sector.

In the light of the previous discussion, especially the issue of weak linkages between rural producers and buyers raised by Addaquay (2011), the main objective of the study was to undertake an analysis of the production, costs, income and constraints related to the picking and processing of shea nut by women farmers in selected districts of the Northern Region of Ghana. The four specific objectives of the study are (1) the ascertain the types of training received by women farmers with respect to their shea nut production and processing activities; (2) to establish the amounts of shea nuts picked by the women farmers, the variation in the amounts picked, and the causes of this variation over time; (3) to establish the amounts of shea nuts processed by the women farmers, the variation in the amounts processed, and the causes of this variation over time and (4) to identify the factors influencing the satisfaction of women farmers for the prices of their shea products that they receive from buyers.

The rest of this paper is organized as follows: the next section discusses the materials and methodology used for the study including sampling procedures and a brief description of the study areas. This section is followed by the discussion of the main results of the study. The conclusions and references form the final part of the paper.

\section{Literature Review: Overview of Political Economy Theories of Productivity in Agriculture}

Various theories have been proposed for understanding the productivity of people in agricultural production and marketing. The major ones include (1) neoclassical economic theories adjusted for the existence of market failures which are pervasive in the so-called "free" markets especially in developing countries, (2) social capital theory, (3) theories based on the new institutional economics and (4) structuralism theories.

When an exchange of a good or service takes place between and among people, a market is said to exist. Neoclassical economic theories envisage the market as an ideal form of production, distribution and exchange of goods and services under a set of favourable conditions. The appropriate variant of neoclassical theories, chosen for our discussion is the mixed economy system, which places importance of markets as an ideal form production for operating an economy, but acknowledges the existence of many failures of the markets which require interventions by the Community and the State to ensure societal optimal outcomes (Hayami, 1989; Hayami, 2009; Anaman, 2014). 
Market failures result from cases where the markets fail to provide adequate incomes for the survival and sustainability of people and their livelihood systems. Anaman (2014, pp. 16-18) provide the general conditions under which "free" markets fail and hence require intervention by the Community of not-for-profit organizations, and the State. The general conditions that lead to market failure include inadequate competition among firms, difficulty to enter and/or exit particular markets by some people based on a variety of factors including discrimination and other artificial barriers, inadequate, unbalanced or asymmetric information about the conditions of markets, production and consumption externalities or interdependencies, acquired and inherited disabilities of some human beings which do not allow them to produce goods and services fully, natural environments which are not conducive for the production of goods and services and lack of basic peace and civil order in a country.

In the discussion context of this paper, the woman shea nut farmer in the Northern Region of Ghana is initially assumed to operate in a "free" market system where she combines her labour with various capital inputs to produce outputs in the form of unprocessed and processed shea nut products which she offers for sale to interested parties. Her performance in the market-based economy is due to her capacity to produce, and her power to negotiate for resources to produce the crop and sell its products. This market-based economy is often not fully competitive and is prone to various failures. A common source of market failure for a woman shea nut farmer is her inadequate access to critical levels of capital inputs that are required to be combined with her labour inputs in sufficient quantities to achieve maximum possible productivity.

As indicated by Buadi et al. (2013), capital inputs used by a farmer can be categorized into six main types. These are (1) physical capital such as seeds and equipment, (2) financial capital such as farmer's own cash or borrowed monies including credit from financial institutions, (3) human capital through means such as health, training and re-training, and general educational improvement of the farmer, (4) information and improved knowledge capital, (5) environmental or natural capital related to environmental support system including climatic and weather conditions and (6) social capital that defines the institutional networks and organizations that support the work of the farmer, for example, farmer-based organizations (FBOs) or cooperatives.

The inadequacies of access to adequate capital inputs by the woman shea nut farmer could be mitigated through her membership of FBOs where she could gain easier access to the five other forms of capital through her share of the inputs mobilized by the entire FBO which she belongs. This point brings to the fore front the theory of social capital which is underpinned by attempts to explain the rationale of people choosing to belong to FBOs and/or pooling together resources to assist themselves. Social capital theories, as used in the context of agriculture and FBOs, are summarized by Hayami (2009). In principle, social capital theories seek to analyse the rationale of individuals pooling together either on a voluntary basis, such as through FBOs or through informal extended family support systems, to improve their welfare.

An overriding driver for the emergence of FBOs and informal family-based associations and welfare groups has been the reciprocity concept whereby an individual gains benefits at a future time for costs incurred in supporting others at earlier times. The reciprocity arrangement often arises from the market failure resulting from in the inability of an individual farmer to generate adequate amounts of income to support his/her family arising from inadequate amounts of capital inputs and resources required to generate adequate livelihood incomes at a particular point in time. When the market system fails to achieve desired outcomes for society, the institutions of the Community and the State often develop to fill this void (Anaman, 2014; Buadi et al., 2013). The Community is largely tied to the concept of social capital.

The third major theory that helps us to understand the productivity of farmers is the new institutional economics, via the theory of transaction costs, which is largely a modification of neoclassical economic theories that allow for better explanation and interpretation of real world phenomena related to productivity linked to costs of facilitating exchange of market goods and services. The theory of transaction costs deals with the actual costs incurred in the exchange of goods and services rather than the actual costs of producing the goods and services themselves (Williamson, 1973; Williamson, 1981). Transaction costs involve three main components. These are (1) search and information-related costs, (2) bargaining costs, and (3) policing and enforcement costs (Dahlman, 1979). The transaction cost theory is related to the mixed economy neoclassical theories as transaction costs merely impose additional costs through the use of financial capital, and information \& knowledge capital available to the farmer to exchange a good. High levels of transaction costs may render the exchange of a good unprofitable even though the actual production of the good may be economically feasible.

In the context of Northern Ghana, shea nut farmers do not plant the trees but rather pick the fruits for sale and/or further processing before selling the processed shea products. The actual work and related costs involved in picking 
the shea nuts tend to be relatively small. The productivity of women is largely linked to the transaction costs dealing with their costs of travelling back from the farm to their places of residence (often their husband's home) after they have picked the shea nuts, the costs involved in selling the nuts and its processed products, their bargaining power with marketing middlemen and companies with respect to the prices that they receive for the nuts, and their ability to enforce agreed contracts with middlemen and companies which buy the nuts from them. Aspects of the transaction costs dealing with the woman shea nut farmer are illustrated in Figure 4 which shows the pictorial linkage of the costs involved in the exchange of the picked shea nut from the farm to the market centre.

Step 1

Figure 4. Conceptual flow of activities of a typical woman shea nut picker from picking to final sales in the Northern region of Ghana 
The fourth major theory that can be used to analyse the productivity of farmers is the structuralism political economy model. The several variants of the structuralism political economy model are summarized by Balam and Veseth (2008) and Sackreyet al. (2008). The general variant of the structuralism political economy models states that dominant groups and classes of human beings shape and determine the economic outcomes of society. In the context of shea nut farming in the Northern region of Ghana, picking of shea nuts is primarily the work of women with very little participation of men. Women do not own the land that they pick the fruits from. Women pick the shea fruits from land explicitly owned by their husbands. Occasionally, women may get a chance to pick from community-owned forests and fields which are largely controlled by men. The position of a particular woman in the commonly-practised polygamous marriage system whereby one man may have several wives determines to a large extent the access of the woman to pick shea nut fruits from the husband's farms.

The productivity of the women is not always due to the extent of their organizational skills and the intensity of labour exerted (that can be indicated by the number of hours worked), but are also influenced by the male-dominated social-cultural systems that define the boundaries of choices and inputs that are available to women. We argue that in order to properly understand the activities of the woman shea nut farmer from the first stage of picking the shea fruits largely from her husband's farm to the end stage of selling the processed shea fruits at market centre, a synthesis of the four main theories may be necessary to capture all the drivers of production and/or marketing activities engaged by the woman.

\section{Methodology}

The survey was conducted in seven leading shea nut producing districts in the Northern Region of Ghana, the most important shea nut producing region in Ghana. Northern Region is one of the ten politically administrative regions of Ghana and is the largest of the ten regions based on land mass. The survey involved 226 women farmers. The seven districts are as follows: (1) Chereponi, (2) Central Gonja, (3) West Gonja, (4) West Mamprusi, (5) Savelugu, (6) Saboba, and (7) Sanarigu (refer to Table 1). The survey covered a period of six months from September 2012 to March 2013 and it involved the use of a questionnaire which was developed from a stakeholder- consultative process involving several meetings and workshops. The questions asked of respondents were designed to allow the researchers to obtain information about the woman farmer-perceived system of production and marketing of the crop that establishes the linkages of processes from the picking of shea nut to final sale at the local market centres. The interviewers were selected based on their local language proficiency and sufficient understanding of the areas. The districts from which communities were selected for the survey were done in consultation with SNV, a local Dutch Non-Governmental Organisation (NGO) which operates in the region.

The districts and communities where the women shea nut farmers and processors were selected and interviewed are listed in Table 1. Shea women picker and processor groups were also contacted for the survey through SNV, which is one of the major NGOs in the Northern Region working with and assisting women shea nut farmers. The SNV field officers in the various communities who worked with the women groups were interviewed also interviewed to elicit information related to the various aspects of production, processing and marketing of shea by women farmers and their various roles in assisting the women groups both in shea nut farming and other farming and non-farming activities of these women.

Table 1. Districts and communities visited during survey in 2013

\begin{tabular}{llllcc}
\hline District & \multicolumn{3}{c}{ Community Names } & $\begin{array}{l}\text { Number } \\
\text { Interviewed }\end{array}$ & Percent \\
\hline West Gonja & BUSUNU (49) & & $\mathbf{4 9}$ & 21.7 \\
\hline Central Gonja & $\begin{array}{l}\text { ALHASSAN } \\
\text { KURAA(7) }\end{array}$ & $\begin{array}{l}\text { DOMEABRA } \\
(14)\end{array}$ & $\begin{array}{l}\text { KURAWURA } \\
\text { KURAA (21) }\end{array}$ & $\mathbf{4 2}$ & 18.6 \\
\hline West Mamprusi & CHERA (24) & ZUA (11) & & $\mathbf{3 5}$ & 15.5 \\
\hline Chereponi & KPENCHI (10) & NANDERE (15) & YETELE (28) & $\mathbf{5 3}$ & 23.5 \\
\hline Savelugu & KUKUO (10) & & & $\mathbf{1 0}$ & 4.4 \\
\hline Saboba & FORO (4) & LIFORIT (6) & WAPULI (23) & $\mathbf{3 3}$ & 14.6 \\
\hline Sanarigu & GRUGU (3) & $\begin{array}{l}\text { KUMBUYILI } \\
(1)\end{array}$ & & $\mathbf{4}$ & 1.8 \\
\hline Total & & & & $\mathbf{2 2 6}$ & $\mathbf{1 0 0 . 0}$ \\
\hline
\end{tabular}




\section{Results and Discussion}

\subsection{Basic Socio-economic Information about Respondents}

Table 2 presents information about selected socio-economic indicators of the 226 women respondents. Forty-six percent of the women were between the ages 15 to 35 , the age group considered to be relatively youthful. A further 37.0 percent of the women were in the middle-age group of between 36 to 59 years. The remaining 17 percent of the respondents were aged 60 and over. Almost nine out of ten women were currently married. Only one woman was divorced. The remaining respondents were widowed. The average household size was 10.4 with a range from two to 40 members suggesting the commonality of polygamous marriages.

The respondents were largely not formally educated with an overwhelming 86 percent never having had any type of formal schooling. Only about three percent of the women had attended senior secondary school. Yet, almost half of the respondents $(48.0 \%)$ had at least one savings account suggesting the possible impact of extension work of FBOs, NGOs and the government in the areas with regard to the use of formal banking services. Of the 226 women respondents, about $69 \%$ of respondents picked shea nuts only. About four percent of the respondents were processors only. The remaining $26.9 \%$ of respondents worked as both pickers and processors. About three out of four (75.1\%) women belonged to local producer/processor associations (farmer-based association). This proportion was almost equal to the $80.1 \%$ of proportion of women who were aware of the existence of local producer/processor association. This finding suggested that non-membership of a farmer-based association might be related to the lack of awareness of the existence of such associations.

Table 2. Summary of socio-economic characteristics of survey respondents

\begin{tabular}{|c|c|}
\hline Item & Percent Frequency \\
\hline \multicolumn{2}{|l|}{ Marital status of respondent } \\
\hline$>$ Married & $89.4 \%$ \\
\hline$>$ Divorced & $0.4 \%$ \\
\hline$>$ Widowed & $10.2 \%$ \\
\hline \multicolumn{2}{|l|}{ Age group of respondent } \\
\hline$>\quad 15-35$ & $46.0 \%$ \\
\hline$>\quad 36-59$ & $37.0 \%$ \\
\hline$>60$ and above & $17.0 \%$ \\
\hline \multicolumn{2}{|l|}{ Formal educational attainment } \\
\hline$>$ No school at all & $86.0 \%$ \\
\hline$>$ Primary or Basic Schooling & $5.0 \%$ \\
\hline$>$ Junior Secondary School/Middle school & $5.0 \%$ \\
\hline$>$ Senior Secondary School & $3.0 \%$ \\
\hline \multicolumn{2}{|l|}{ Other major occupation outside shea nut farming } \\
\hline$>$ Other farming activities & $68.5 \%$ \\
\hline$>$ Trading & $19.2 \%$ \\
\hline$>$ Food vending & $7.4 \%$ \\
\hline \multicolumn{2}{|l|}{ Major occupation of spouse } \\
\hline$>$ Farmer & $88.8 \%$ \\
\hline$>$ Teacher & $3.1 \%$ \\
\hline$>$ Trader & $2.0 \%$ \\
\hline$>\quad$ All others & $6.1 \%$ \\
\hline \multicolumn{2}{|l|}{ Type of shea activity } \\
\hline$>$ Picking only & $69.1 \%$ \\
\hline$>$ Processing only & $4.0 \%$ \\
\hline$>$ Both picking and processing & $26.9 \%$ \\
\hline \multicolumn{2}{|l|}{ Ownership of a savings account } \\
\hline$>$ Yes & $48.0 \%$ \\
\hline$>$ No & $52.0 \%$ \\
\hline \multicolumn{2}{|l|}{ Membership of a producer/processor association } \\
\hline$>$ Yes & $75.1 \%$ \\
\hline$>\mathrm{No}$ & $24.9 \%$ \\
\hline
\end{tabular}




\subsection{Training and Human Capital Development for Women Shea Nut Farmers}

With reference to the first objective of the study, the production of a crop requires some training and education, either formal or informal or both, as crop production and management skills have to be transferred from one group of people (teachers) to others. Training, as outlined earlier in the context of human capital improvement, is a key tool for improving the productivity of farmers, based on the mixed-economy neoclassical economic view point and it is an important tool to reduce market failure resulting from inadequate and unbalanced information about shea nut farming.

The survey results reported in Table 3 show that the most popular forms of training based on proportions of farmers receiving the training were marketing of shea $(45.6 \%)$, shea nut processing $(44.5 \%)$ and shea butter production (38.9\%). Table 4 indicates that the majority of the training programmes were recent having been conducted in 2011 and 2012 (65.9\%; almost two-thirds of the programmes) compared to 2013 when this survey was undertaken. The least popular training programmes were in those related to managerial skills such as financial management $(0.4 \%)$, record keeping (21.2\%), and management of associations (23.9\%) (refer to Table 3).

A question that arises then is why are women farmers less involved in the training of managerial skills given their relatively high participation in the area of skills related to the production and marketing of the product? This question naturally leads to two issues: (1) providers of these training programmes and (2) the degree and level of transaction costs related to travel and search costs that must be incurred by farmers to attend these programmes. The training programmes were largely organized by the private companies which bought shea from the women farmers and processors at venues and sites which were cost-effective for these companies.

Given the low formal educational attainment of respondents (refer to Table 2), training and re-training programmes offer a good avenue for the human capital improvement of farmers. Hence obstacles and barriers, such as high transaction costs related to travel and search costs, that prevent women from participating more fully in such training and re-training programmes become a key area for intervention by the State or government to reduce the market failure associated with poor managerial skills related to shea nut farming and processing.

This finding suggests a renewed role for the agricultural extension services of the Ministry of Food and Agriculture (MoFA) in the area left void by the private companies. Private companies which are mainly interested in making profits are not likely to be very interested in the improvement of managerial skills of women farmers - an essential key to the improvement of livelihood and poverty reduction. MoFA should therefore use its extension services to complement the work of private companies by focusing on managerial skills of women farmers in the larger context of adult education related to numeracy and writing skills.

Table 3. Types of training received by women shea nut farmers

\begin{tabular}{lll}
\hline Type of Training Received & $\begin{array}{l}\text { Number of Women Who Had } \\
\text { Received } \\
\text { Training }\end{array}$ & $\begin{array}{l}\text { Number of Women Who Had } \\
\text { not Received this Type of } \\
\text { Training }\end{array}$ \\
\hline Shea Nut Processing & $100(44.5 \%)$ & $126(55.5 \%)$ \\
\hline Shea Butter Production & $88(38.9 \%)$ & $138(61.1 \%)$ \\
\hline Marketing of Shea & $103(45.6 \%)$ & $123(54.4 \%)$ \\
\hline Management of Associations & $54(23.9 \%)$ & $172(76.1 \%)$ \\
\hline Financial Management & $1(0.4 \%)$ & $225(99.6 \%)$ \\
\hline Record Keeping & $48(21.2 \%)$ & $178(78.8)$ \\
\hline
\end{tabular}

Note: The figures in parentheses represent the proportions as expressed in percentages. The number of women shea nut farmers was 226. 
Table 4. Last time respondents were trained and the number of training programmes for each reference year

\begin{tabular}{lll}
\hline Year & $\begin{array}{l}\text { Number of training } \\
\text { programmes held } \\
\text { during the year }\end{array}$ & $\begin{array}{l}\text { Percentage of the total number } \\
\text { of training programmes from } \\
\text { 2001 to 2012 conducted during } \\
\text { the year }\end{array}$ \\
\hline 2001 & 2 & 0.4 \\
\hline 2005 & 4 & 0.7 \\
\hline 2008 & 52 & 9.5 \\
\hline 2009 & 111 & 20.3 \\
\hline 2010 & 18 & 3.3 \\
\hline 2011 & 237 & 43.3 \\
\hline 2012 & 124 & 22.6 \\
\hline Total & 548 & 100.0 \\
\hline
\end{tabular}

\subsection{Shea Nut Picking (Production)}

With respect to the second objective of the study, shea nut picking, which can be considered the production stage of the shea business, is a predominantly female work. When the women respondents were asked during the survey whether males were getting involved in the picking of shea nuts, $93.1 \%$ of these respondents indicated that males were not getting involved. Only $15(6.9 \%)$ of the 217 respondents who answered the question indicated yes. Structuralism political economy theories, which emphasise that dominant groups or classes in society shape and/or determine economic outcomes (refer to Balaam and Veseth, 2008; Sackrey et al., 2008), are a useful tool for analysis of shea nut farming in the Northern Region of Ghana, as the structure of the socio-cultural system assigns women to the traditional role of picking shea nuts, a role that had not changed over time as was observed during the survey. Hence, given this socio-cultural structure that women face, which is not likely to be changed in the near future, the results of this study are useful in identifying the other production and marketing constraints, and suggesting various ways through which these other constraints could be relaxed for increased women productivity and welfare.

About 96 percent of respondents are engaged in the picking of shea nuts from various locations (refer to Table 2). The amounts of shea nuts picked, measured using the easily-identified local scale weights, are presented in Table 5 for the five-year period from 2008 to 2012. There had been inter-annual variation of yields of shea nuts picked with 2008 being the year of maximum output based on the relatively high numbers of maxi bags and mini bags harvested. The reasons for inter-annual variation of outputs of shea nuts picked or harvested are summarized in Table 6 based on information from 200 out of the 226 respondents who provided answers to the question on this issue. The most important factor indicated by $39 \%$ of respondents for the inter-annual variation was poor yields due essentially to the weather and climate. The second most important factor was noted specifically as climatic conditions indicated by $20.5 \%$ of respondents.

It is clear from Table 6 that the inter-annual variations in output harvested through picking are largely influenced by climatic conditions and variability as expressed by almost $60 \%$ of respondents. This result also shows that environmental capital inputs available to the farmer, based on the environmental support system including climatic conditions and resources, was the most critical factor influencing output of harvested shea nuts. Hence the market failure resulting from low harvested outputs from picked shea nuts is directly linked to the level and quality of environmental capital system available to the farmer which often she has little control to alter.

The third most important reason given by respondents for inter-annual variation in yields of harvested shea nuts is the health problems of the picker. This reason was given by over one-sixth of respondents (17.5\%). This result illustrates that the problem of low and/or unstable outputs of harvested shea nuts is also linked to the level of quality of human capital as expressed through the health status of the farmer. While training programmes are essential factors to influence the degree of human capital of the farmer through education, the health status of the farmer is an important human capital factor as shown in Table 6. Financial problems, often cited by economists and development practitioners, as a major cause of low outputs of small scale famers and pickers in Africa, were ranked as not very important. Only $3.5 \%$ of respondents indicated financial problems as a major factor for inter-seasonal variation in outputs of harvested shea nuts (refer to Table 6). 
Table 5. Quantities of shea nuts picked by respondents during a season expressed using recognised local weight scales from 2008 to 2012

\begin{tabular}{llllll}
\hline Year & Bowls & Olonka & Pan & Mini bag & Maxi Bag \\
\hline 2008 & 3 & 0 & 0 & 13 & 18 \\
\hline 2009 & 3 & 0 & 3 & 7 & 7 \\
\hline 2010 & 14 & 2 & 9 & 7 & 7 \\
\hline 2011 & 11 & 3 & 11 & 8 & 7 \\
\hline 2012 & 11 & 3 & 3 & 7 & 4 \\
\hline Total & $\mathbf{4 2}$ & $\mathbf{8}$ & $\mathbf{2 6}$ & $\mathbf{4 2}$ & $\mathbf{4 3}$ \\
\hline
\end{tabular}

Notes: A bowl is approximately 3 kilogrammes $(\mathrm{kg})$; an olonka is approximately $5 \mathrm{~kg}$; a pan is approximately $10 \mathrm{~kg}$; a mini bag is $50 \mathrm{~kg}$ and maxi bag is $85 \mathrm{~kg}$.

Table 6. Reasons indicated by respondents for the variation in the outputs harvested through picking of shea nuts over the 2008 to 2012 period

\begin{tabular}{llc}
\hline Reason & Number of Respondents & Percentage of Respondents \\
\hline Poor yields & 78 & 39.0 \\
\hline Climatic conditions & 41 & 20.5 \\
\hline Health problems of the picker & 35 & 17.5 \\
\hline Seasonal changes or variations & 28 & 14.0 \\
\hline Financial problems & 7 & 3.5 \\
\hline Bush burning & 5 & 2.5 \\
\hline Lack of help from family members & 3 & 1.5 \\
\hline Competition from other pickers & 2 & 1.0 \\
\hline Old age & 1 & 0.5 \\
\hline Total & $\mathbf{2 0 0}$ & $\mathbf{1 0 0 . 0}$ \\
\hline
\end{tabular}

\subsection{Shea Nut Purchases and Sales}

About $51.6 \%$ of respondents indicated that they bought shea nuts from various marketing outlets. The reasons for the purchases of shea nuts are varied. About 62.0 percent of respondents indicated that they bought the shea nuts with the purpose of selling them later at higher prices. The average selling prices for shea kernels (obtained by peeling the shea nuts) as provided by the respondents over the 2008 to 2012 period are reported in Table 7 . The average prices for shea kernels had fluctuated over the five-year period reflecting the supply and demand interactions.

About $19.3 \%$ of respondents bought the shea nuts for processing and further sale while about $18.6 \%$ bought the shea nuts for processing for home and family use. These results illustrated the transaction cost principle derived from the new institutional economics theories. The majority of the women (62.0\%) realized that they could provide a profitable service by re-selling the shea nuts directly and/or further processing as the additional benefits outweighed the additional costs of selling (including processing if any). The transaction cost principle is supported by the choice of place that the respondents chose to sell their shea nuts (refer to Table 8 ). Slightly over half $(50.2 \%)$ of respondents indicated that they sold their shea nuts at their places of residence which meant relatively little transaction cost related to travel to local market centres to sell the products, Not surprisingly, another $10.5 \%$ of respondents also indicated that they sold their shea nuts on the farm after they have picked the nuts also illustrating the relatively low transaction cost chosen by sellers.

The use of local market centres to sell shea nuts was also important and this medium was used by slightly over one-third of respondents (35.6\%). The use of other market outlets for sales, which was mainly through wholesale markets, was the choice of about $3.6 \%$ of respondents (refer to Table 8 ). The cost of marketing shea nuts at local market centres, based on both transportation costs and local government taxes, was estimated to be an average of 18.7 Ghana cedis (GHS) for the season made up of GHS16.2 for transportation costs from the community to market centres and GHS2.5 for local government taxes. The dominant choice of respondents for the use of their places of residence and their farms as the selling places for disposal of their shea nuts reflected their determination to avoid the transaction cost related to the marketing of the products at local market centres (refer to Table 8). 
Table 7. Average selling prices for shea kernels for picked by respondents during a season expressed using recognised local weight scales from 2008 to 2012 in GHS

\begin{tabular}{lllll}
\hline Year & Bowl & Pan & Mini bag & Maxi Bag \\
\hline 2008 & 2.20 & 8.00 & 15.00 & 60.50 \\
\hline 2009 & 3.50 & 19.00 & 24.00 & 54.38 \\
\hline 2010 & 1.89 & 10.94 & 38.50 & 58.55 \\
\hline 2011 & 1.65 & 7.65 & 44.94 & 43.50 \\
\hline 2012 & 1.75 & 9.71 & 43.50 & 74.70 \\
\hline
\end{tabular}

Notes: A bowl is approximately 3 kilogrammes $(\mathrm{kg})$; an olonka is approximately $5 \mathrm{~kg}$; a pan is approximately $10 \mathrm{~kg}$; a mini bag is $50 \mathrm{~kg}$ and maxi bag is $85 \mathrm{~kg}$.

Table 8. Places where respondents indicated that they sold their shea nuts in the season

\begin{tabular}{llc}
\hline Place shea nuts were sold & Number of sales & Percentage \\
\hline At the residence of the picker & 278 & 50.3 \\
\hline At local market centres & 197 & 35.6 \\
\hline On the farm & 58 & 10.5 \\
\hline Wholesale market within the district & 16 & 2.9 \\
\hline Wholesale market outside the district & 3 & 0.5 \\
\hline Others & 1 & 0.2 \\
\hline Total & 553 & 100.0 \\
\hline
\end{tabular}

\subsection{Shea Nut Processing}

With reference to the third objective of the study, it is clear that women do process shea nuts into butter and soap components for use of their families or for sales to companies and other retail outlets. The survey, reported in this paper, elicited information on the processing of shea nuts by the women respondents. The majority of processors $(60.7 \%)$ had been undertaking this activity for one to ten years while another $18 \%$ had been in the processing business for between 11 to 20 years. About $60.6 \%$ of respondents indicated a purely commercial motive for the processing of shea nuts while about $30.3 \%$ processed shea nuts mainly for domestic (family) use. The remaining nine percent of respondents who processed shea nuts did so for both commercial and home consumption motives. Table 9 summarises information provided by the respondents on the amounts of shea nuts that they processed over the 2008 to 2012 period. Inter-annual fluctuations in amounts of shea nuts processed are shown in Table 9 though outputs of processed shea nuts measured in maxi bags had increased over the last two years of the five-year period.

The reasons for inter-annual variation of the amounts of shea nuts processed are reported in Table 10 using information from 40 respondents who processed shea nuts and were willing to provide relevant data. Similar to the earlier section dealing with the picking of shea nuts, the most dominant factor influencing inter-annual variability in the processing of shea nuts was directly related to poor yields and seasonal fluctuations related to the weather and climate (refer to Table 10). The four most important factors highlighted by respondents for the fluctuations in outputs processed are all interconnected and directly linked to unstable weather and climatic conditions.

This result once again illustrates the importance of the natural or environmental capital as probably the most important constraint facing the farmer in both the picking and processing of shea nuts. Free markets therefore can and do fail often due to unstable or low levels of natural or environmental capital stocks and inputs, and these failures do occur not because of lack of enthusiasm or energy of the farmer but factors beyond the control of the farmer. The other two major factors affecting the fluctuations in outputs of shea nuts processed were financial problems and old age/health problems of processors. Financial problems were only cited by $12.5 \%$ of processors and old age/health problems indicated by another $5 \%$ of processors. 
Table 9. Average quantities of shea nuts processed by respondents during a season expressed using local weight scales from 2008 to 2012

\begin{tabular}{lrlll}
\hline Year & Bowl & Pan & Mini bag & Maxi Bag \\
\hline 2008 & 7.67 & 4.50 & 6.80 & 5.67 \\
\hline 2009 & 7.75 & 7.33 & 5.00 & 4.25 \\
\hline 2010 & 5.00 & 6.67 & 4.10 & 7.75 \\
\hline 2011 & 13.36 & 2.00 & 4.50 & 13.62 \\
\hline 2012 & 12.89 & 2.17 & 3.67 & 20.48
\end{tabular}

Notes: A bowl is approximately 3 kilogrammes $(\mathrm{kg})$; an olonka is approximately $5 \mathrm{~kg}$; a pan is approximately $10 \mathrm{~kg}$; a mini bag is $50 \mathrm{~kg}$ and maxi bag is $85 \mathrm{~kg}$.

Table 10. Reasons indicated by respondents who processed shea nuts for the variation in the outputs processed over the 2008 to 2012 period

\begin{tabular}{lll}
\hline Reason & $\begin{array}{l}\text { Number of Respondents Indicating } \\
\text { this Factor }\end{array}$ & $\begin{array}{l}\text { Percentage } \\
\text { Respondents }\end{array}$ \\
\hline Seasonal changes or variations & 11 & 27.5 \\
\hline Low yields & 9 & 22.5 \\
\hline Scarcity & 7 & 17.5 \\
\hline Climatic conditions & 6 & 15.0 \\
\hline Financial problems & 5 & 12.5 \\
\hline Health problems & 1 & 2.5 \\
\hline Old age of respondent & 1 & 2.5 \\
\hline Total & $\mathbf{4 0}$ & $\mathbf{1 0 0 . 0}$ \\
\hline
\end{tabular}

\subsection{Sales of Processed Shea Nut Products - Butter and Soap}

As indicated earlier, the processing of shea nuts yields two major products - shea butter and shea soap - which are widely used locally and also exported to overseas markets. The survey sought information about the level of production of butter and soap from the women respondents over a five-year period from 2008 to 2012. The places where the processed shea butter and shea soap were sold were also elicited from the respondents. For the shea butter, about two-thirds of the respondents $(67.1 \%)$ indicated that it was sold at local market centres. About $29.1 \%$ of respondents indicated that shea butter was sold at the house or residence of the processor while the factory was used as the source of sales by remaining $3.7 \%$ of processors. For shea soap, there were only two identified source of sales point - market $(75 \%)$ and house $(25 \%)$. The nearest place for selling was considered the most important factor in deciding the source of sales point.

The quantities of shea butter and shea soap sold by the women respondents are presented in Tables 11 and 12 respectively. Data for quantities of shea soap sold were scanty hence the analysis in this section focuses on the sales of shea nut butter. As shown in Table 11 the reported quantities of shea nut butter sold fluctuated over the 2008 to 2012 period. Respondents indicated that the fluctuating sales were caused by factors in order of importance as follows: (1) low yields (30\%), (2) seasonal changes (30\%), (3) scarcity (20\%), (4) financial problems (10\%) and (5) no clear reasons $(10 \%)$. The importance of these factors in influencing the volume of sales of shea nut is consistent with those offered for the fluctuations in the level of picking of shea nuts (refer to Table 6) and the level of processing of shea nuts (refer to Table 10). The most important factors affecting the level of sales of processed shea butter were related to the seasonality of production related to weather and climatic variability. 
Table 11. Average quantities of shea nut butter sold by respondents during a season expressed using recognised local weight scales from 2008 to 2012

\begin{tabular}{lllll}
\hline Year & Calabash & Bowls & Hand mould & Boxes \\
\hline 2008 & 7.70 & 5.00 & 10.00 & NA \\
\hline 2009 & 7.25 & 7.00 & 2.00 & NA \\
\hline 2010 & 7.04 & 6.60 & 49.50 & 50.00 \\
\hline 2011 & 8.61 & 62.00 & 33.33 & 62.00 \\
\hline 2012 & 6.55 & 45.55 & 3.00 & 26.40 \\
\hline
\end{tabular}

Notes: A standard calabash full of shea butter weighs 9 kilogrammes $(\mathrm{kg})$; a bowl of shea butter is approximately 5 $\mathrm{kg}$; a hand mould weighs about $0.5 \mathrm{~kg}$; a standard box weighs $25 \mathrm{~kg}$.

Table 12. Average quantities of shea nut soap sold by respondents during a season expressed using recognised local weight scales from 2008 to 2012

\begin{tabular}{lllll}
\hline Year & Calabash & Bowls & Hand mould & Boxes \\
\hline 2008 & 1.00 & NA & NA & NA \\
\hline 2009 & 1.00 & NA & NA & NA \\
\hline 2010 & 1.00 & NA & NA & NA \\
\hline 2011 & 9.67 & 1.50 & NA & NA \\
\hline 2012 & 7.00 & 1.50 & NA & NA
\end{tabular}

Notes: A standard calabash full of shea butter weighs 9 kilogrammes $(\mathrm{kg})$; a bowl of shea butter is approximately 5 $\mathrm{kg}$; a hand mould weighs about $0.5 \mathrm{~kg}$; a standard box weighs $25 \mathrm{~kg}$.

\subsection{Contract Relationships between Sellers and Buyers of Shea Products}

The fourth objective of the study dealt with the process of bargaining between sellers and buyers of shea nut products. This issue is an important component of the shea nut value chain with policy concerns as to its equity in the distribution of incomes between producers, processors and buyers. The underlying theoretical principle is the transactions costs principle embedded in the new institutional economic theories as discussed earlier in the literature review section. The survey sought information directly from the women respondents on a number of issues related to the three transaction costs components of (1) search and information, (2) bargaining, and (3) policing \& enforcement.

The respondents indicated that the major buyers of the shea kernel that they produced were in order of importance as declared by the proportions of respondents: middlemen (50.2\%), local individual buyers (20.9\%), Pure Company (14.2\%), other locally-based companies (13.9\%), and SNV (0.8\%). For the shea butter, the most important buyers were local individual consumers (53.6\%), middlemen (41.3\%), NGOs (2.6\%), exporters $(1.9 \%)$ and factory $(0.7 \%)$. The greater importance of middlemen and companies in the purchase of shea kernel (nut) was shown as compared to the purchase of shea butter which was dominated by individual consumers.

Concerning the search and information component of transaction cost principle as it related to transactions between sellers and buyers of shea products, we established that there were three major market information needs based on the proportions of respondents' expressions. These needs were (1) pricing (61.9\%), buyer preferences (25.4\%) and quantity requirements $(12.7 \%)$. As to the sources where these information needs could be addressed, producer/processor associations was the most important source of information on markets accessed by respondents based on $38.9 \%$ of respondents expressing this source. This was followed in order of importance by radio (31.4\%), friends, especially fellow women on an informal basis (14.3\%), mobile phones (7.6\%), agents $(6.2 \%)$ and buyers $(1.9 \%)$.

The bargaining component of the transaction cost principle involves negotiating between buyers and sellers to settle on agreed prices, quantities and qualities of goods to be supplied. As indicated in Table 13, 59.2\% of the women respondents indicated that they had either written or oral contracts with the buyers and customers of their products. A significantly large minority of sellers (40.8\%) did not have contracts with buyers and customers. Information from Table 13 shows that the largest subgroup (43.7\%) of women respondents considered the buyer to be the main determinant of the prices of their shea products (buyer market). Those who considered the seller as the 
dominant person deciding on the prices of shea products were the second largest subgroup (26.1\%) (seller market). Bargaining (18.0\%) and consensual agreement (12.0\%) were the other two sources of determinants of prices of shea nut products. Bargaining and consensual agreement (30\%) would represent the views of respondents who considered the market to be fairly competitive without the advantage of buyers or sellers.

The majority of respondents $(57 \%)$ were moderately satisfied with the prices received while another $21.0 \%$ highly satisfied with the prices received with the prices received. However, almost one in four respondents (22\%) was not satisfied with the prices received. A question dealing with power influences in the bargaining processes related to the setting of prices of shea products was what factors accounted for the differences in the level of price satisfaction sellers who had contracts and those who did not have contracts? A related issue deals with how contracts agreed between buyers and sellers are enforced (policing and enforcement component of the transaction costs).

Table 13. Information on the contracts relations between sellers and buyers of shea nut products elicited from the women respondents

\begin{tabular}{lc}
\hline \multicolumn{1}{c}{ Item } & Percent Frequency \\
\hline $\begin{array}{l}\text { Existence of contract between responding woman seller and her } \\
\text { buyers and customers } \\
>\quad \text { Yes }\end{array}$ \\
$>$ No & \\
\hline If a contract exists, what type of contract & $59.2 \%$ \\
$>$ Written & $40.8 \%$ \\
$>$ Oral & $50.6 \%$ \\
$>$ Both & $48.4 \%$ \\
\hline Who determines the prices of your products & $1.0 \%$ \\
$>$ Seller (respondent herself) & \\
$>$ Buyer & $26.1 \%$ \\
$>$ Consensus & $43.7 \%$ \\
$>$ Bargaining & $12.2 \%$ \\
\hline Level of satisfaction of prices received for products & $18.0 \%$ \\
$>$ High & \\
$>$ Medium & $21.0 \%$ \\
$>$ Low & $57.0 \%$ \\
\hline
\end{tabular}

We used Chi-square statistical analysis to test the statistical association between the woman shea nut farmer's degree of satisfaction with the prices of shea products and following four variables based on a pair wise comparison. The four variables were (1) having oral and written contracts with buyers (2) the type of economic agent that determined market prices based on the perceptions of the woman respondent, (3) having a savings account and (4) belonging to a producer/processor group. The Chi-square Pearson coefficient of association was highly significant at least at the 0.02 probability level for all the four individual comparisons.

Since Chi square analysis connotes only statistical association and not causation, we used a multiple regression analysis to estimate the relationship between the woman shea nut farmer's degree of satisfaction with prices that she receives for her shea products (dependent variable) with a number of independent variables. The multiple regression model is as follows:

PRICESATISFACTION $_{\mathrm{i}}=$ B $_{\mathbf{0}}+$ B $_{1}$ HAVECONTRACT $_{\mathbf{i}}+$ B $_{2}$ GROUPMEMBER $_{\mathrm{i}}+$ B $_{3}$ SAVINGACCOUNT $_{\mathrm{i}}+$ B $_{4}$ BUYERMARKET $_{i}+$ B $_{5}$ GROUPMEMBERWC $_{i}+\mathbf{U}_{\mathrm{i}}$

where PRICESATISFACTION was the perceived level of satisfaction of prices received by the woman respondent based on a Likert-type scale with 3 denoting high satisfaction, 2 denoting moderate level of satisfaction, 1 denoting low level of satisfaction; 
HAVECONTRACT is a dummy variable with 1 representing a woman respondent with written and/or contracts with buyers of various shea products and zero otherwise. The a priori expectation is that women with contracts will have more satisfaction with the prices that they receive based on the increased likelihood that the prices agreed upon will actually be paid and that the prices negotiated will be satisfactory to the seller before she commits to the contract given that shea nuts are not easily perishable.

GROUPMEMBER was a dummy variable with 1 indicating that the woman belonged to a producer/processor group and zero otherwise. It is expected that women who belong to groups will be more satisfied with prices received based on the greater bargaining power of the group as compared to a single individual. This is akin to the countervailing power of groups such as trade unions and farmer-based groups developed by the American political economist, John Kenneth Galbraith in 1952.

SAVINGACCOUNT was a dummy variable with 1 indicating that the woman respondent had a savings account and zero otherwise. It is postulated that women with savings accounts have received some training from various NGOs and have more information about market opportunities that allows them to bargain for better prices for their products.

BUYERMARKET was a dummy variable with 1 indicating that the woman respondent considered the market to be a buyer market and zero otherwise. Structuralism political economy theories suggest that a buyer market is a structure that favours buyers due to power concentrations.

GROUPMEMBERWC was a dummy variable with 1 indicating that the woman respondent was a member of a producer/buyer association, and also had a written or verbal contract with the buyer or customer, and zero otherwise.

$\mathrm{U}$ was the error term initially assumed to have zero mean and constant variance.

The results of the regression analysis are reported in Table 14. The power of the model was modest especially given the cross-sectional nature of the data with $\mathrm{R}^{2}$ of about $13 \%$. Despite the modest $\mathrm{R}^{2}$, the model was correctly specified based on the Ramsey Reset test. The null hypothesis of adequately correct model specification could not be rejected ( $\mathrm{p}$ value of 0.617). Further, the variance inflation factor for all the five independent variables were less than the critical value of 10 suggested by Gujarati (2009) for the absence of the econometric problem of multicollinearity. There was no statistically significant spatial autocorrelation as measured by the Durbin-Watson test. The model was considered good such that it could be used for discussion and interpretative work. All the five variables were strongly statistically significant in influencing the dependent variable - the degree of price satisfaction of respondents related to the markets for shea products. Being a member of an FBO, having a savings account, and having a contract with buyers positively influenced respondents' satisfaction of prices received. As expected, the perception of the existence of a buyer market, a market controlled by middlemen and companies, led to reduced price satisfaction. A (buyer) market that is largely controlled by middlemen and companies can be considered to be non-competitive and a source of market failure due to power concentration.

The interaction term of group membership and having a contract at the same time (GROUPMEMBERWC) was strongly statistically significant but had a negative sign. The interpretation could be that respondents, who were members of FBOs and had written/oral contracts with buyers, were less satisfied than those who either did not have contracts with buyers and/or were members of FBOs. This could be possible due to the high expectation of price satisfaction for women who were members of FBOs and at the same time had contracts with buyers; this high expectation was probably not met. This could also be due to inadequate policing and enforcement of contracts, the third component of transaction cost indicated in the literature review section. While membership of FBOs was positive and useful by itself, and a contract was also useful by itself, it was important for the contract to be effectively enforced. Without enforcement of contracts, the respondent in that situation probably felt worse than somebody who did not have contracts with buyers at all.

The standardized regression estimates indicated that the most important variable influencing the degree of price satisfaction was the variable indicating both having a contract and being a member of a group, once again reinforcing the importance of the enforcement principle associated with contracts. Further, the second most important variable was having a contract, followed by the presence of a buyer market, being a member of an FBO and having a savings account. The importance of having contracts with buyers that are enforceable, the importance of women joining FBOs, and having savings accounts emanate from this study. Ensuring more competitive markets by reducing excessive powers of middlemen and companies, the provision of information to women to have enforceable contracts with buyers of their products, and the need for them to join FBOs to enhance their collective bargaining power in dealing with buyers are important government intervention tools that can help to enhance the welfare of women. 
Table 14. Results of the multiple regression analysis of factors influencing the degree of satisfaction for prices of shea products received by the women respondents

The dependent variable was PRICESATISFACTION, the perceived level of satisfaction of prices received

\begin{tabular}{lccccc}
\hline Explanatory Variable & $\begin{array}{c}\text { Parameter } \\
\text { Estimate }\end{array}$ & $\begin{array}{c}\text { Standardised } \\
\text { Parameter } \\
\text { Estimate }\end{array}$ & $\begin{array}{c}\text { Student t } \\
\text { value }\end{array}$ & $\begin{array}{c}\text { Probability } \\
\text { level of } \\
\text { significance }\end{array}$ & $\begin{array}{c}\text { Variance } \\
\text { Inflation } \\
\text { Factor (VIF) }\end{array}$ \\
\hline INTERCEPT & 1.853 & 0.000 & 23.300 & $0.000^{* * *}$ & 1.000 \\
\hline HAVECONTRACT & 0.458 & 0.350 & 3.051 & $0.002^{* * *}$ & 6.045 \\
\hline GROUPMEMBER & 0.294 & 0.193 & 3.405 & $0.001 * * *$ & 1.473 \\
\hline SAVINGACCOUNT & 0.175 & 0.135 & 2.767 & $0.006^{* * *}$ & 1.094 \\
\hline BUYERMARKET & -0.323 & -0.248 & -5.130 & $0.000^{* * *}$ & 1.069 \\
\hline GROUPMEMBERWC & -0.565 & -0.423 & -3.461 & $0.001 * * *$ & 6.850 \\
\hline
\end{tabular}

Notes on Table 14:

(1) The sample size used for the analysis was 203 due to missing values of some variables.

(2) The $R^{2}$ was 0.128 ; the adjusted $R^{2}$ was 0.117 and was statistically significant at the 0.000 level.

(3) Probability level of significance of model specification based on the

Ramsey Reset test for the null hypothesis of correct model specification

(4) Probability level of significance of the autocorrelation based on the

Durbin-Watson test for the null hypothesis of no autocorrelation

(5) The triple asterisk $(* * *)$ denotes statistical significance at the $1 \%$ level.

\section{Conclusions and Recommendations}

The survey, reported in this paper, provides evidence-based information on the production, marketing and the constraints facing women shea nut farmers in selected districts of the Northern Region of Ghana. We were guided by mix of inter-related theories that are linked to an understanding of the persistent causes of market failures. Farmer satisfaction of prices received for their shea products was related to their membership of farmer-based organizations and having enforceable contracts with buyers. The role of farmer education and improvement of her health status are important in the empowerment of women and their ability to negotiate better market outcomes

The reduction of these market failures has largely been undertaken through efforts from farmer-based organizations with little inputs from the government. In fact, about $96 \%$ of the survey respondents indicated that they had received no assistance from government agencies in their shea activities and enterprises. It is important for the government to undertake intervention measures to assist women shea nut farmers, particularly in the areas of market infrastructure to reduce the overall cost of travelling from farm to markets that is realized with the development of better motorable roads. Another government intervention will be to provide improved information through reinvigorated extension services of MoFA to women farmers on the development of enforceable contracts with buyers and the encouragement of these farmers to operate savings accounts with existing rural banks and the encouragement of non-members to join FBOs which have shown clear ability to assist women farmers improve their livelihoods through shea nut farming. A major government intervention that is needed is the expansion of community and government-owned forests through planting of more shea trees. This will allow increased and expanded access of women to large areas to pick the shea nuts and also assist in the improvement of environmental capital stock of the Northern Region of Ghana.

We conclude this paper by noting some limitations of the study. These limitations include the fact that the survey was conducted only in the Northern Region of Ghana and not the other two major shea growing regions of the country - Upper East and Upper West Regions. The limitation of the geographical area of the study was due to limited funds. Hence the conclusions of the study are limited to the Northern Region rather than all the shea growing areas of Ghana. Another limitation is the absence of analysis dealing with net incomes from shea nut picking and processes as productivity is linked to the generation of net incomes. In the future, we plan another paper that deals with factors influencing incomes of shea nut women farmers based on using the existing data collected from the survey. 


\section{Acknowledgments}

We thank all the participating farmers and institutions in the Northern Region of Ghana for their assistance in the collection of data. This study was financed with a grant from the Volkswagen Foundation, Frankfurt, Germany.

\section{References}

Addaquay, J. (2004). The Shea Butter Value Chain, Refining in West Africa. WATH Technical Report No. 3. Dakar: WATH.

Addaquay, J. (2011). Ghana Business Communities. Retrieved 15 December 2014, from www.ghanabusinesscommunities.com

Anaman, K. A. (2014). Research Methods in Economics and Other Social Sciences (2 ${ }^{\text {nd }}$ ed.). Saarbrucken, Germany: Lambert Academic Publishing.

Balaam, D. N., \& Veseth, M. (2008). Introduction to International Political Economy (4 $4^{\text {th }}$ ed.). New York: Pearson and Prentice Hall.

Bonkoungou, E. (1987). Monographie du Karité Butyrospermum Paradoxum (Gaertn. f.) Hepper, Espèce Agroforestière à Usage Multiple. Ouagadougou Burkina-Faso: Institut de Recherche en Biologie et Ecologie Tropicale.

Buadi, D. K., Anaman, K. A., \& Kwarteng, J. A. (2013). Farmers' Perceptions of the Quality of Farmers' Perceptions of the Quality of Extension Services Provided by Non-governmental Organisations in Two Municipalities in the Central Region of Ghana. Agricultural Systems, 120, 20-26.

Chalfin, B. (2004). Shea Butter Republic, State Power, Global Markets and the Making of an Indigenous Commodity. New York: Psychology Press.

Dahlman, C. J. (1979). The Problem of Externality. Journal of Law and Economics, 22(1), 141-162.

Elias, M., \& Carney, J. (2007). African Shea Butter: A Feminised Subsidy from Nature. Africa, 77(1), 37-62.

Food and Agriculture Organisation. (1988). Forest Genetic Resource Priorities (Appendix 5). Report of Sixth Session of the FAO Panel of Exports on Forest Gene Resources, 8-11 December 1985, Rome, Italy, 79, 86-89.

Galbraith, J. K. (1952). American Capitalism. Boston: Houghton Mifflin.

Ghana Statistical Service (GSS). (2014). Report of the Ghana Living Standards Survey Round 6 (2012/2013). Accra, Ghana: GSS.

Gujarati, N. (2009). Basic Econometrics (5 ${ }^{\text {th }}$ ed.). Singapore: McGraw Hill.

Hall, J. B., Aebischer, D. P., Tomlinson, H. F., Osei-Amaning, E., \& Hecht, T. (1996). A Review of Feeds and Fertilizers for Sustainable Aquaculture Development in Sub-Saharan Africa. In Hasan, M.R., Hecht, T., De Silva, S.S. and Tacon, A.G.J. (Eds.), Study and Analysis of Feeds and Fertilizers for Sustainable Aquaculture Development (pp. 77-109). Rome, Italy: Food and Agriculture Organisation.

Hatskevich, A., Jenicek, V., \& Antwi Darkwah, S. (2011). Shea industry - A Means of Poverty Reduction in Northern Ghana. Agricultura Tropica et Subtropica, 44, 223-228.

Hayami, Y. (1989). Community, Market and State. In Maunder, A.A. and Valdes, A. (Eds.), Proceedings of the $20^{\text {th }}$ International Conference of Agricultural Economists, Buenos Aires, Argentina (pp.24-31). London: Dartmouth Press.

Hayami, Y. (2009). Social Capital, Human Capital, and the Community Mechanism: Toward A Conceptual Framework for Economists. Journal of Development Studies, 45(1), 96-123.

Lovett, J. C., Midgley, G. F., \& Barnard, P. (2005). Climate Change and Ecology in Africa. African Journal of Ecology, 43(3), 167-169.

Sackrey, C., Schneider, G., \& Knoedler, J. (2008). Introduction to Political Economy (5 ${ }^{\text {th }}$ ed.). Boston: The Economic Affairs Bureau.

Stathacos, C. (2004). The Shea Butter Value Chain, The US Market Study. WATH Technical Report Number 4. Dakar: WATH.

Williamson, O. (1973). Markets and Hierarchies: Some Elementary Considerations. American Economic Review, 63(2), 316-325.

Williamson, O. (1981). The Economics of Organization: The Transaction Cost Approach. The American Journal of Sociology, 87(3), 548-577. 